\title{
Acute safety assessment of lithium bioacummulated in mycelial biomass of Ganoderma lucidum
}

\section{Avaliação aguda da segurança do lítio bioacumulado em biomassa micelial de Ganoderma lucidum}

Gustavo Ratti da Silva ${ }^{1}$, Eduarda Carolina Amaral $^{1}$, Maria Luiza Marchi Silva ${ }^{1}$, Aniely Oliveira Silva ${ }^{1}$, Leila Isabel da Silva ${ }^{1}$, Diego Lacir Froehlich ${ }^{2}$, Maria Graciela Iecher Faria ${ }^{1}$, Giani Andrea Linde ${ }^{3}$, Nelson Barros Colauto ${ }^{3}$, Evellyn Claudia Wietzikoski Lovato ${ }^{1}$, Francislaine Aparecida dos Reis Lívero ${ }^{1 *}$

\begin{abstract}
RESUMO
O lítio é um tratamento de primeira linha para o transtorno bipolar, um transtorno caracterizado pela alternância de episódios maníacos e depressivos. No entanto, devido ao seu índice terapêutico estreito, o lítio pode causar efeitos adversos. A associação do lítio com moléculas mais complexas, como proteínas e polissacarídeos, pode auxiliar no controle da liberação de lítio em todo o sistema digestivo, reduzindo assim as doses que são utilizadas pelos pacientes e, consequentemente, reduzindo os efeitos adversos. O presente estudo avaliou a toxicidade oral aguda do lítio bioacumulado na biomassa micelial de Ganoderma lucidum, etapa de pesquisa que antecede os estudos de eficácia pré-clínica. O estudo seguiu a diretriz da Organização para Cooperação e Desenvolvimento Econômico. Ratos Wistar machos $(n=6)$ foram tratados agudamente por gavagem com doses fixas (300 e $2000 \mathrm{mg} / \mathrm{kg}$ ) de lítio bioacumulado na biomassa micelial de $G$. lucidum. Foram avaliadas alterações nos sinais clínicos, massa corporal, massa relativa dos órgãos, parâmetros bioquímicos, hemograma, leucócitos e alterações histopatológicas. Um grupo de animais que foram tratados com veículo $(n=6)$ serviu como grupo basal. Não foram observados sinais de toxicidade em nenhum dos parâmetros investigados. A bioacumulação de lítio na biomassa micelial de G. lucidum não induziu sinais de toxicidade em ratos tratados agudamente por via oral.
\end{abstract}

Palavras-chave: Basidiomicetos; Transtorno bipolar; Depressão; Mania; Cogumelo.

\section{ABSTRACT}

Lithium is a first-line treatment for bipolar disorder, a disorder that is characterized by alternating manic and depressive episodes. However, because of its narrow therapeutic index, lithium can cause adverse effects. The association of lithium with more complex molecules, such as proteins and polysaccharides, may help control the release of lithium throughout the digestive system, thereby reducing the doses that are used by patients and consequently reducing adverse effects. The present study evaluated the acute oral toxicity of lithium bioaccumulated in mycelial biomass of Ganoderma lucidum, a research step that precedes preclinical efficacy studies. The study followed Organization for Economic Cooperation and Development guideline. Male Wistar rats $(\mathrm{n}=6)$ were acutely treated by gavage with fixed doses $(300$ and $2000 \mathrm{mg} / \mathrm{kg}$ ) of lithium bioaccumulated in mycelial biomass of G. lucidum. Changes in clinical signs, body mass, relative organ mass, biochemical parameters, blood count, leukocytes, and histopathological changes were evaluated. A group of animals that were treated with vehicle $(n=6)$ served as the basal group. No

\footnotetext{
${ }^{1}$ Paranaense University, Umuarama, Paraná, Brazil

${ }^{2}$ Assis Gurgacz Faculty, Cascavel, PR, Brazil

${ }^{3}$ Federal University of Bahia, Bahia, Brazil

* E-mail: francislaine@prof.unipar.br
} 
signs of toxicity were observed in any of the investigated parameters. Lithium bioaccumulation in mycelial biomass of G. lucidum did not induce signs of toxicity in rats that were acutely orally treated.

Keywords: Basidiomycetes; Bipolar disorder; Depression; Mania; Mushroom.

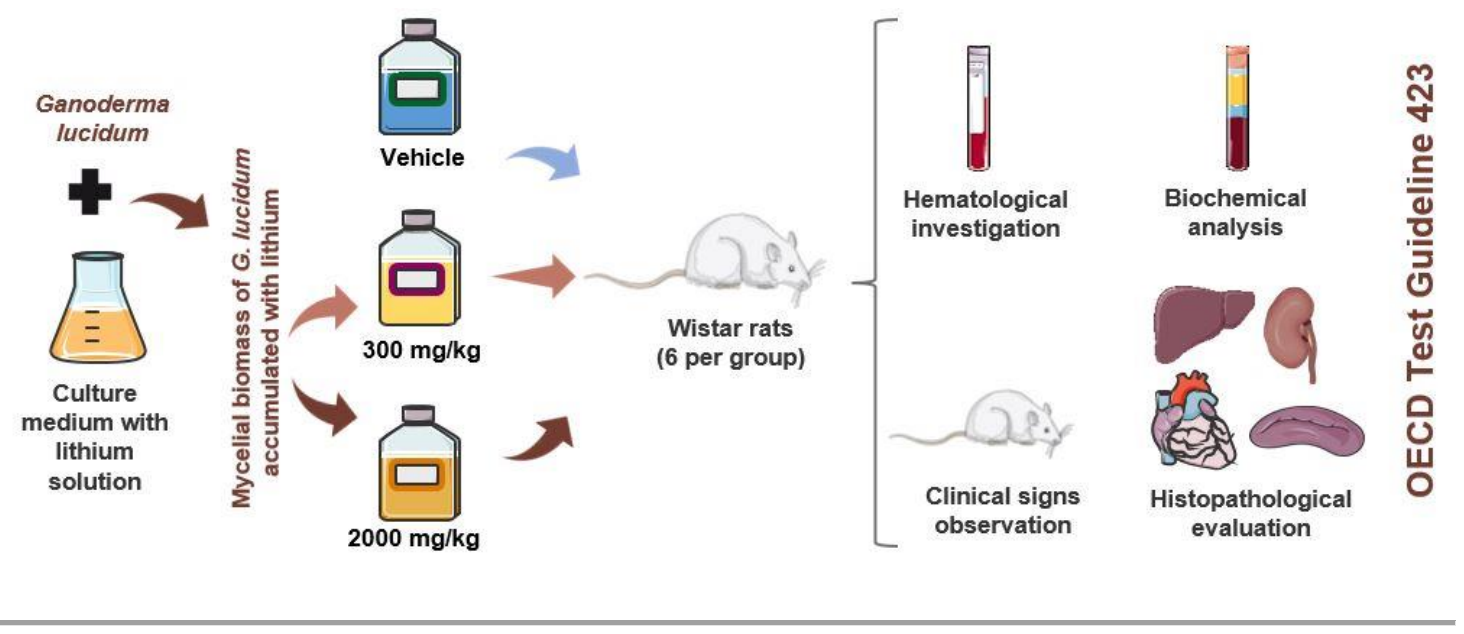

\section{INTRODUCTION}

Ganoderma lucidum (Curtis) P. Karst. (Basidiomycotaete: Polyporales) has the ability to bioaccumulate metals of nutritional and pharmacological interest in its mycelial structures (MENIQUETI et al., 2020; SCHEID et al., 2020; UMEO et al., 2020; MATUTE et al., 2011; MENIQUETI et al., 2021). The bioaccumulation of metals in basidiomycetes is a particularly interesting strategy to control the solubility and availability of metals. This occurs through the association of ions with complex organic compounds, such as proteins and polysaccharides, that are slowly digested and release minerals throughout the digestion process (FARIA et al., 2019).

One of these metals, lithium, is a first-line treatment for bipolar disorder, which exerts preventive actions against suicide (CHI-TSO and CHUANG, 2011). Bipolar disorder is a chronic or episodic mental disorder (i.e., it may occur only occasionally or at irregular intervals). It is characterized by manic and depressive phases that can cause unusual, often extreme, and fluctuating changes in mood, energy, activity, and concentration or focus. It is a common, serious, chronic, and often life-threatening disease that affects $0.5-1 \%$ of the population worldwide (CARDOSO et al., 2015).

Lithium carbonate has been the first treatment choice for this psychiatric illness. It is absorbed in the gastrointestinal tract and excreted by the kidneys (WARING et al., 2002). The treatment concentration of lithium can vary from 0.5 to $1.2 \mathrm{mM}$, but its mechanism of action has caused doubts because of its narrow therapeutic index. Another 
concern of lithium is its effects on kidney function, which may be impaired during treatment. The therapeutic plasma concentration of lithium is normally between 5.6 and $8.4 \mathrm{mg} / \mathrm{L}$, and its toxic concentration is above $10.5 \mathrm{mg} / \mathrm{L}$ (SMITH and CIPRIANI, 2017).

Based on the importance of lithium for the treatment of psychiatric diseases, its bioavailability and effectiveness need to be controlled. One promising option may be its bioaccumulation in basidiomycetes. The solubility of lithium can be controlled when it is associated with organic macromolecules, such as polysaccharides and proteins, which can assist with controlled release and make treatment safer (AIDA et al., 2009). Thus, lithiumenriched fungal biomass could be a supplementation option for the treatment of bipolar mood disorders. However, despite the relevance of lithium to the treatment of psychiatric diseases and the potential production of lithium bioaccumulated fungi as a source of lithium, no studies have investigated the toxicity of lithium bioaccumulated in a myiceliall biomass of G. lucidum, which was the goal of the present study.

\section{MATERIAL AND METHODS}

- Lithium bioaccumulated in a mycelial biomass of Ganoderma lucidum

Ganoderma lucidum (U17-1) from the Culture Collection of the Molecular Biology Laboratory, Universidade Paranaense (Umuarama, PR, Brazil), was used. This strain was registered (code no. A04E776) in the Sistema Nacional de Gestão do Patrimônio Genético e Conhecimentos Tradicionais Associados (SisGen), Brazil. The mycelium was added to malt extract agar $(20 \mathrm{~g} / \mathrm{L})$, previously autoclaved at $121^{\circ} \mathrm{C}$ for 20 min, and grown in the dark at $28^{\circ} \mathrm{C} \pm 1^{\circ} \mathrm{C}$ for 10 days. The homogeneous mycelia without sectorization was selected as the inoculum. Erlenmeyer flasks that contained liquid culture medium based on sugarcane molasses $(20 \mathrm{~g} / \mathrm{L})$ were autoclaved at $121^{\circ} \mathrm{C}$ for 20 min. Afterward, a solution of lithium carbonate (Reatec $\left.{ }^{\circledR}\right)$ that was previously sterilized was added to the medium to obtain a final concentration of 30 parts per million (ppm) of lithium. Each Erlenmeyer flask was inoculated with three disks ( $0.5 \mathrm{~mm}$ diameter $)$ of the culture medium that contained the mycelia. Mycelial biomass growth occurred at $28^{\circ} \mathrm{C} \pm$ $1{ }^{\circ} \mathrm{C}$ for 21 days in the dark, without shaking. The mycelial biomass was dehydrated at $60^{\circ} \mathrm{C}$ until a constant mass was obtained. Lithium extraction followed the methodology of Yokota et al. (2016). The determination of lithium concentrations in the samples was performed by atomic flame absorption spectrophotometry (GBC model 932 plus). For 
lithium quantification, a calibration curve was used $(\mathrm{R} 2=0.998)$ with an analytical standard (IAA-203 Lot K00461 ultra scientific analytical solutions) with a detection limit of $0.01 \mathrm{mg} / \mathrm{ml}$. The concentration of lithium per gram of biomass was $246.81 \mu \mathrm{g}$.

\section{- Experimental animals}

The acute toxicity of lithium accumulated in mycelial biomass was evaluated in male Wistar rats of 300-400 g, obtained from the State University of Maringá (UEM). The animals were housed in the vivarium of the UNIPAR Neuroscience Laboratory with free access to a liquid and solid diet under controlled environmental conditions (temperature: $20^{\circ} \mathrm{C} \pm 2{ }^{\circ} \mathrm{C}$; relative humidity: $50 \% \pm 10 \% ; 12 \mathrm{~h} / 12 \mathrm{~h}$ light/dark cycle). The animal protocols were approved by the Ethics Committee in Research Involving Animal Experimentation of UNIPAR (protocol no. 1006/2019). The animals received environmental enrichment. All guidelines and recommendations with regard to animal welfare, reducing the number of animals and reporting animal research were followed (PERCIE DU SERT et al., 2020).

\section{- Experimental design}

The animals were randomly assigned to groups $(n=6 /$ group $)$. The rats' group assignments were marked on the tail. The rats were housed in rectangular polypropylene boxes for 10 days before beginning the experiments to allow acclimatization to the laboratory conditions. The lethal dose (LD50) was determined according to Organization for Economic Cooperation and Development (OECD) guideline 423. Groups of animals were dosed in a stepwise manner using fixed doses of 5, 50, 300, and $2000 \mathrm{mg} / \mathrm{kg}$. The initial dose was $300 \mathrm{mg} / \mathrm{kg}$ because there is no information on a substance to be tested. Other groups of animals were dosed with higher or lower fixed doses, depending on the presence or absence of signs of toxicity or mortality. This procedure was performed until the dose that caused evident toxicity or not more than one death was identified, when no effect was observed at the highest dose, or when deaths occurred at the lowest dose. After an $8 \mathrm{~h}$ fast, the lithium bioaccumulated in mycelial biomass was administered orally by gavage in a single dose (Fig. 1). Following treatment, the rats were fasted for an additional 4 h. One group of animals $(n=6)$ that was treated with vehicle (deionized water) served as the basal group. 
Figure 1- Acute toxicology test according to OECD Guideline 423, presenting the process for the lethal dose (LD50) cut-off value determination for lithium bioaccumulated in mycelial biomass of Ganoderma lucidum. The study was conducted in a stepwise manner, with the use of three animals of a single sex per step. The determination of acute toxicity of the test substance is based on the mortality and/or moribund status of the animals, and 2-4 steps may be necessary for such an evaluation. The starting dose (300 mg/kg in this study) is tested once. If 2 3 animals died, then this was followed by testing a lower fixed dose. If one or no animals die, then the starting dose is tested twice, and a higher fixed dose level is used in the next step until the appropriate Globally Harmonized System category of toxicity is reached.

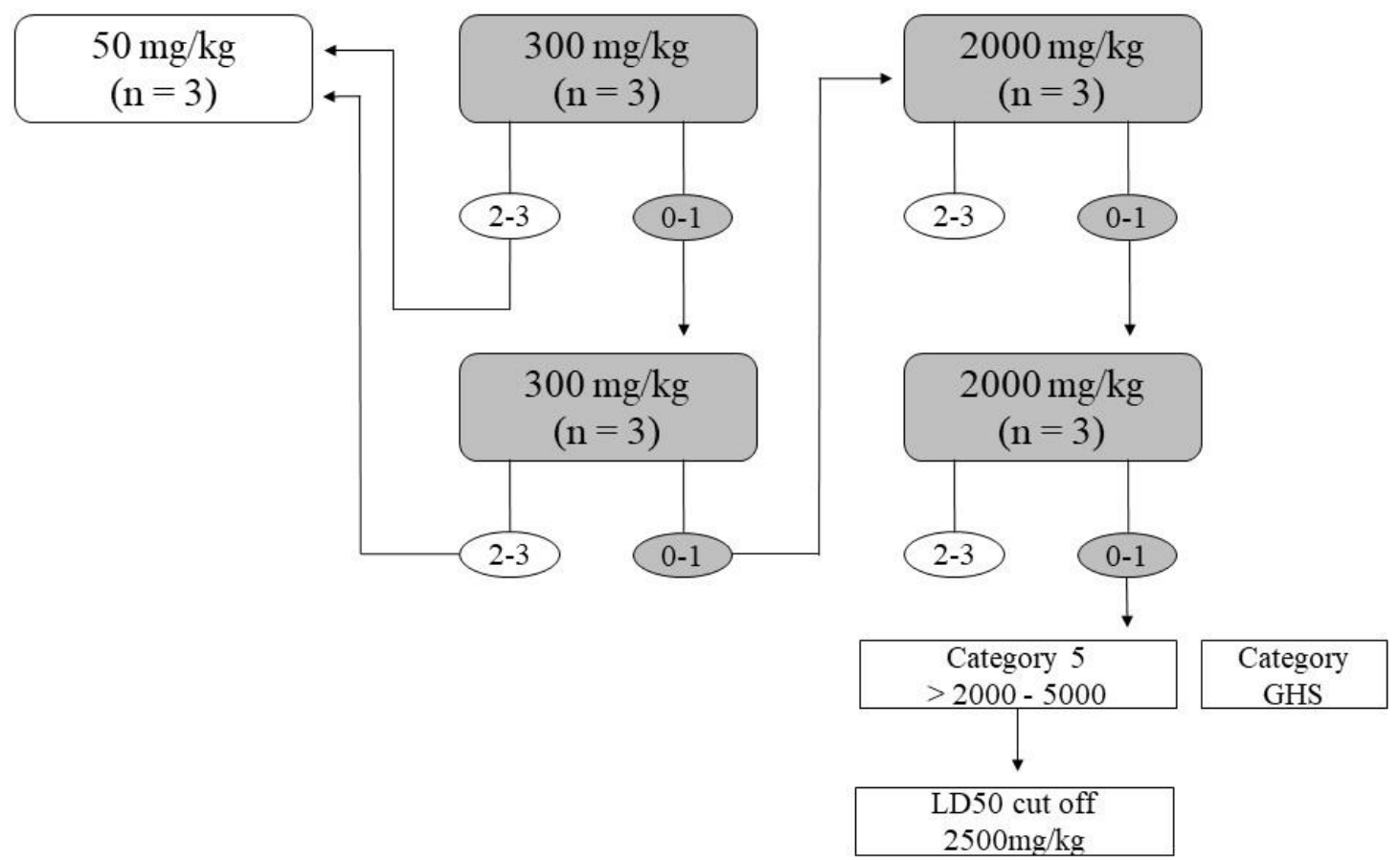

- Assessment of clinical signs

After administering the lithium bioaccumulated in mycelial biomass of $G$. lucidum, the animals were monitored during the first $30 \mathrm{~min}$ and then 1, 2, 3, and $4 \mathrm{~h}$ after treatment. Behavioral parameters and clinical signs (i.e., self-cleaning, piloerection, dyspnea, abdominal constriction, diarrhea, prostration, ataxia, sedation, coma, and death) were recorded according to the method of Almeida et al. (1999). After the first $4 \mathrm{~h}$ of observation, the animals received water and food and were observed daily for 14 days to record clinical changes and deaths. 


\section{- Euthanasia and material collection}

On day 15 , after fasting for $12 \mathrm{~h}$, the rats were euthanized by deep anesthesia with isoflurane in a saturation chamber (1-3\%). Blood was collected by decapitation. Levels of cholesterol, triglycerides, aspartate aminotransferase, alanine aminotransferase, urea, and creatinine were determined using commercial kits in an automated system. Red blood cell counts, hemoglobin, hematocrit, mean corpuscular volume, mean corpuscular hemoglobin, mean corpuscular hemoglobin concentration, leukocytes, rods, lymphocytes, and platelets were recorded. The liver, spleen, heart, and kidneys were removed, carefully dissected, and weighed on an analytical balance. For kidney mass, the average mass between the right and left sides was used. The mass of each organ was multiplied by 100 and divided by the animal's body weight before euthanasia to obtain the relative organ mass $(\%)$.

\section{- Histopathological analysis}

Fragments of the liver, spleen, heart, kidney, and brain were carefully removed, washed with ice-cold saline, and packed in $10 \%$ buffered formalin. After standard histological processing, the sections were stained with hematoxylin and eosin and histopathologically analyzed by a pathologist veterinarian. The slides were analyzed under a Leica DM 2500 optical microscope to detect cellular changes that resulted from the treatments according to Lima et al. (2019) and Souza et al. (2020).

\section{- $\quad$ Statistical analysis}

The data were first analyzed for homogeneity of variance and a normal distribution. One-way analysis of variance (ANOVA) was then used, followed by the Newman-Keuls post hoc test. The level of significance was $95 \%(\mathrm{p} \leq 0.05)$. For the statistical analysis and generation of the graphs, GraphPad Prism 6.0 software was used.

\section{RESULTS}

\section{- Evaluation of clinical signs}

Acute oral treatment with 300 and $2000 \mathrm{mg} / \mathrm{kg}$ of lithium bioaccumulated in mycelial biomass of Ganoderma lucidum did not induce changes in clinical signs in the animals compared with the basal group. Only diarrhea was observed in one rat $4 \mathrm{~h}$ after 
treatment with $300 \mathrm{mg} / \mathrm{kg}$ and in one rat 1 and $2 \mathrm{~h}$ after treatment with $2000 \mathrm{mg} / \mathrm{kg}$ of lithium bioaccumulated in mycelial biomass of G. lucidum (Table 1).

Table 1 - Evaluation of clinical signs in rats that were acutely orally treated with vehicle (basal group) or lithium bioaccumulated in mycelial biomass of Ganoderma lucidum (300 or $2000 \mathrm{mg} / \mathrm{kg}$ ).

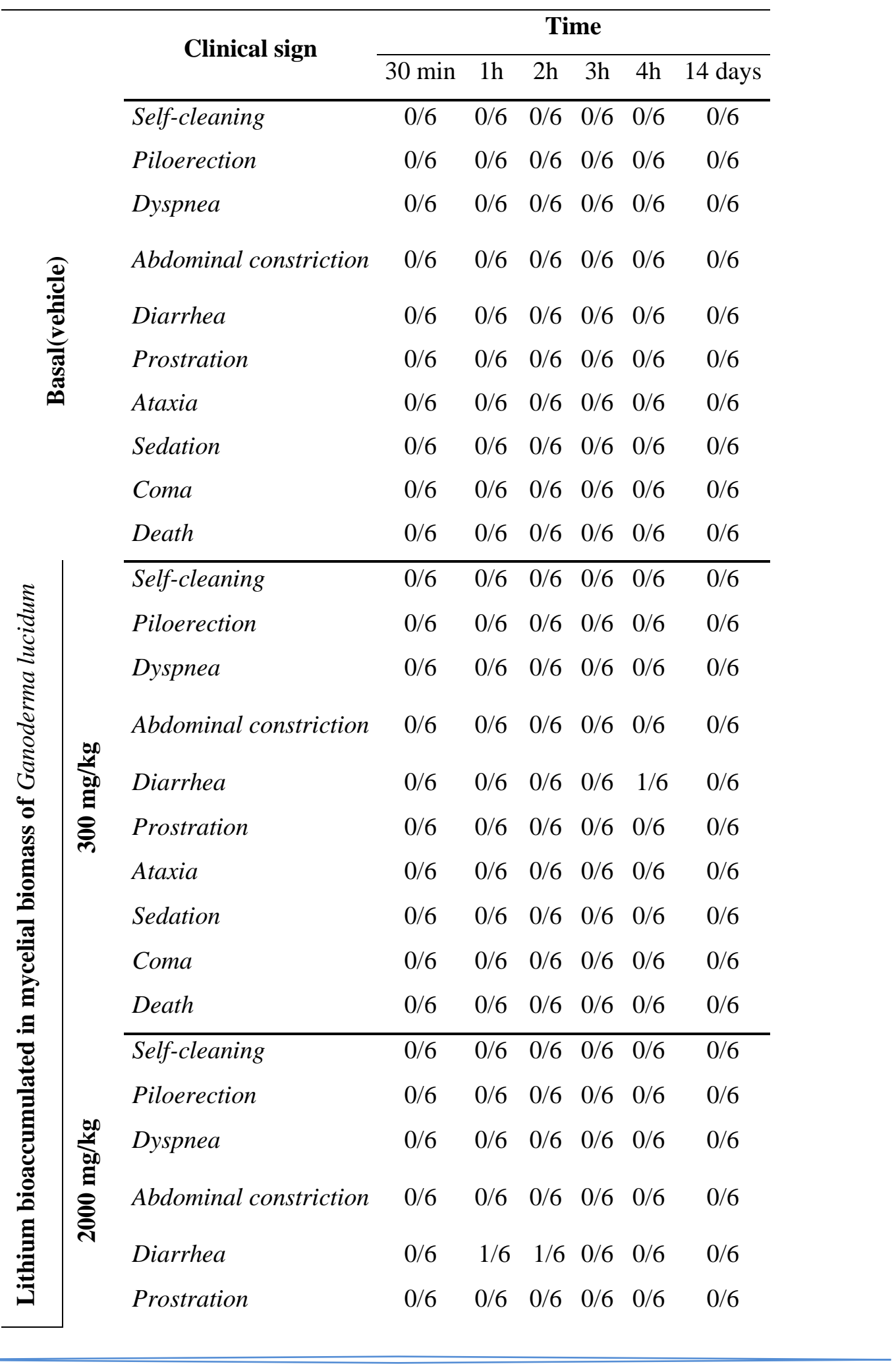




\begin{tabular}{lllllll}
\hline Ataxia & $0 / 6$ & $0 / 6$ & $0 / 6$ & $0 / 6$ & $0 / 6$ & $0 / 6$ \\
Sedation & $0 / 6$ & $0 / 6$ & $0 / 6$ & $0 / 6$ & $0 / 6$ & $0 / 6$ \\
Coma & $0 / 6$ & $0 / 6$ & $0 / 6$ & $0 / 6$ & $0 / 6$ & $0 / 6$ \\
Death & $0 / 6$ & $0 / 6$ & $0 / 6$ & $0 / 6$ & $0 / 6$ & $0 / 6$ \\
\hline
\end{tabular}

- Lithium bioaccumulated in mycelial biomass of Ganoderma lucidum did not induce changes in body mass or relative organ mass in rats

Treatment with 300 and $2000 \mathrm{mg} / \mathrm{kg}$ of lithium bioaccumulated in mycelial biomass of G. lucidum did not induce body mass loss or changes in the relative mass of the liver, spleen, kidneys, or heart compared with the basal group (Table 2).

Table 2 - Body weight and relative organ weight in rats that were acutely orally treated with vehicle (basal group) or lithium bioaccumulated in mycelial biomass of Ganoderma lucidum (300 or $2000 \mathrm{mg} / \mathrm{kg}$ ). Differences between groups were analyzed using one-way ANOVA. The data are expressed as mean $\pm \operatorname{SEM}(n=6$ /group).

\begin{tabular}{|c|c|c|c|}
\hline \multirow{2}{*}{ Day } & \multirow{2}{*}{ Basal } & \multicolumn{2}{|c|}{$\begin{array}{l}\text { Lithium bioaccumulated in mycelial biomass of } \\
\text { Ganoderma lucidum }\end{array}$} \\
\hline & & $300 \mathrm{mg} / \mathrm{kg}$ & $2000 \mathrm{mg} / \mathrm{kg}$ \\
\hline \multicolumn{4}{|c|}{ Body mass $(g)$} \\
\hline 1 & $359.2 \pm 18.46$ & $385.8 \pm 14.11$ & $391.7 \pm 10.86$ \\
\hline 2 & $359.2 \pm 19.08$ & $324.5 \pm 57.52$ & $387.7 \pm 11.17$ \\
\hline 3 & $359.0 \pm 19.27$ & $391.3 \pm 14.39$ & $384.5 \pm 10.69$ \\
\hline 4 & $357.4 \pm 18.58$ & $387.2 \pm 13.61$ & $382.2 \pm 9.78$ \\
\hline 5 & $355.0 \pm 18.73$ & $373.8 \pm 12.73$ & $377.0 \pm 9.42$ \\
\hline 6 & $354.6 \pm 18.58$ & $373.0 \pm 15.02$ & $372.7 \pm 9.78$ \\
\hline 7 & $352.0 \pm 18.55$ & $375.5 \pm 13.86$ & $368.2 \pm 8.97$ \\
\hline 8 & $350.2 \pm 19.19$ & $369.2 \pm 15.31$ & $364.0 \pm 9.40$ \\
\hline
\end{tabular}




\begin{tabular}{cccc}
\hline 9 & $347.2 \pm 19.73$ & $366.7 \pm 15.74$ & $363.8 \pm 10.84$ \\
10 & $345.2 \pm 20.63$ & $367.2 \pm 14.82$ & $363.8 \pm 11.06$ \\
11 & $344.6 \pm 20.51$ & $366.5 \pm 14.68$ & $359.5 \pm 11.46$ \\
12 & $338.0 \pm 17.43$ & $360.7 \pm 16.18$ & $355.5 \pm 11.44$ \\
13 & $332.6 \pm 18.89$ & $359.5 \pm 14.60$ & $351.0 \pm 9.73$ \\
14 & $323.0 \pm 18.19$ & $349.2 \pm 12.18$ & $342.8 \pm 7.95$ \\
\hline Liver & $3.70 \pm 0.129$ & $3.59 \pm 0.067$ & $3.51 \pm 0.150$ \\
Spleen & $0.14 \pm 0.005$ & $0.15 \pm 0.007$ & $0.14 \pm 0.006$ \\
Heart & $0.34 \pm 0.008$ & $0.35 \pm 0.004$ & $0.36 \pm 0.009$ \\
Kidneys & $0.33 \pm 0.006$ & $0.34 \pm 0.005$ & $0.34 \pm 0.010$ \\
\hline
\end{tabular}

- Biochemical profile of rats treated with lithium bioaccumulated in mycelial biomass of Ganoderma lucidum

Acute oral treatment with 300 and $2000 \mathrm{mg} / \mathrm{kg}$ of lithium bioaccumulated in mycelial biomass of G. lucidum did not induce changes in cholesterol, triglycerides, urea, creatinine, aspartate, or alanine aminotransferase compared with the basal group (Table $3)$.

Table 3 - Biochemical profile of rats that were acutely orally treated with vehicle (Basal group) or lithium bioaccumulated in mycelial biomass of Ganoderma lucidum (300 or $2000 \mathrm{mg} / \mathrm{kg}$ ). Differences between groups were analyzed using one-way ANOVA. The data are expressed as mean $\pm \operatorname{SEM}(n=6$ /group).

\begin{tabular}{|c|c|c|c|}
\hline \multirow[t]{2}{*}{ Parameter } & \multirow[t]{2}{*}{ Basal } & \multicolumn{2}{|c|}{$\begin{array}{c}\text { Lithium bioaccumulated in } \\
\text { mycelial biomass of } \\
\text { Ganoderma lucidum }\end{array}$} \\
\hline & & $300 \mathrm{mg} / \mathrm{kg}$ & $2000 \mathrm{mg} / \mathrm{kg}$ \\
\hline Cholesterol (mg/dl) & $68.00 \pm 3.80$ & $76.00 \pm 4.39$ & $71.33 \pm 4.24$ \\
\hline
\end{tabular}




\begin{tabular}{cccc} 
Triglycerides $(\mathrm{mg} / \mathrm{dl})$ & $84.17 \pm 9.61$ & $84.83 \pm 7.48$ & $79.67 \pm 4.91$ \\
Urea $(\mathrm{mg} / \mathrm{dl})$ & $32.87 \pm 1.02$ & $37.47 \pm 1.51$ & $34.95 \pm 2.16$ \\
Creatinine $(\mathrm{mg} / \mathrm{dl})$ & $0.28 \pm 0.01$ & $0.30 \pm 0.00$ & $0.30 \pm 0.00$ \\
Aspartate aminotransferase $(I U / L)$ & $126.30 \pm 15.41$ & $137.50 \pm 8.89$ & $165.50 \pm 21.47$ \\
Alanine aminotransferase (IU/L) & $75.50 \pm 6.51$ & $61.17 \pm 3.14$ & $64.67 \pm 4.76$ \\
\hline
\end{tabular}

- Lithium bioaccumulated in mycelial biomass of Ganoderma lucidum did not induce changes in the hematological profile of rats

No alterations of the hematological profile were observed in rats that were acutely orally treated with 300 or $2000 \mathrm{mg} / \mathrm{kg}$ of lithium bioaccumulated in mycelial biomass of Ganoderma lucidum compared with the basal group (Table 4).

Table 4 - Hematological profile of rats that were acutely orally treated with vehicle (Basal group) or the mycelial biomass of Ganoderma lucidum with accumulated lithium (300 or $2000 \mathrm{mg} / \mathrm{kg}$ ). Differences between groups were analyzed using one-way ANOVA. The data are expressed as mean \pm SEM ( $n=6 /$ group).

\begin{tabular}{|c|c|c|c|}
\hline \multirow[t]{2}{*}{ Parameter } & \multirow[t]{2}{*}{ Basal } & \multicolumn{2}{|c|}{$\begin{array}{c}\text { Lithium bioaccumulated in } \\
\text { mycelial biomass of Ganoderma } \\
\text { lucidum }\end{array}$} \\
\hline & & $300 \mathrm{mg} / \mathrm{kg}$ & $2000 \mathrm{mg} / \mathrm{kg}$ \\
\hline Red blood cells $(M / \mu l)$ & $8.89 \pm 0.28$ & $9.12 \pm 0.21$ & $9.307 \pm 0.21$ \\
\hline Hemoglobin $(g / d l)$ & $17.75 \pm 0.57$ & $17.32 \pm 0.86$ & $18.38 \pm 0.37$ \\
\hline Hematocrit (\%) & $53.38 \pm 1.70$ & $53.70 \pm 1.70$ & $54.67 \pm 1.15$ \\
\hline Mean corpuscular volume (fl) & $60.00 \pm 0.45$ & $58.78 \pm 0.51$ & $58.73 \pm 0.34$ \\
\hline Mean corpuscular hemoglobin (pg) & $19.93 \pm 0.15$ & $18.93 \pm 0.55$ & $19.77 \pm 0.10$ \\
\hline $\begin{array}{c}\text { Mean corpuscular hemoglobin } \\
\text { concentration }(\mathrm{g} / \mathrm{dl})\end{array}$ & $33.25 \pm 0.02$ & $32.15 \pm 0.68$ & $33.63 \pm 0.31$ \\
\hline Leukocyte $\left(10^{2} U / \mu l\right)$ & $5.74 \pm 0.93$ & $6.03 \pm 1.39$ & $8.18 \pm 3.29$ \\
\hline $\operatorname{Rods}(U / \mu l)$ & $0.00 \pm 0.00$ & $0.00 \pm 0.00$ & $0.00 \pm 0.00$ \\
\hline Segmented $\left(10^{2} U / \mu l\right)$ & $3.28 \pm 6.16$ & $2.67 \pm 0.72$ & $6.53 \pm 2.48$ \\
\hline
\end{tabular}


Lymphocyte $\left(10^{2} \mathrm{U} / \mathrm{\mu l}\right)$

Platelets $\left(10^{3} \mathrm{U} / \mu \mathrm{l}\right)$
$2.45 \pm 0.42$

$3.29 \pm 0.73$

$4.52 \pm 1.23$

$580.00 \pm 254.24 \quad 522.33 \pm 80.47$

- Lithium bioaccumulated in the mycelial biomass of Ganoderma lucidum did not induce cellular changes in rats

Treatment with 300 and $2000 \mathrm{mg} / \mathrm{kg}$ of lithium bioaccumulated in mycelial biomass of G. lucidum did not induce cellular alterations in the liver, spleen, heart, or kidneys compared with the basal group (Fig. 2).

Figure 2 - Histopathological evaluation of the liver, spleen, heart, and kidneys in rats that were acutely orally treated with vehicle (Basal group) or lithium bioaccumulated in mycelial biomass of Ganoderma lucidum (300 or $2000 \mathrm{mg} / \mathrm{kg}$ ). Liver, spleen, and heart: $20 \times$ magnification; Kidneys: 40× magnification (hematoxylin/eosin staining).

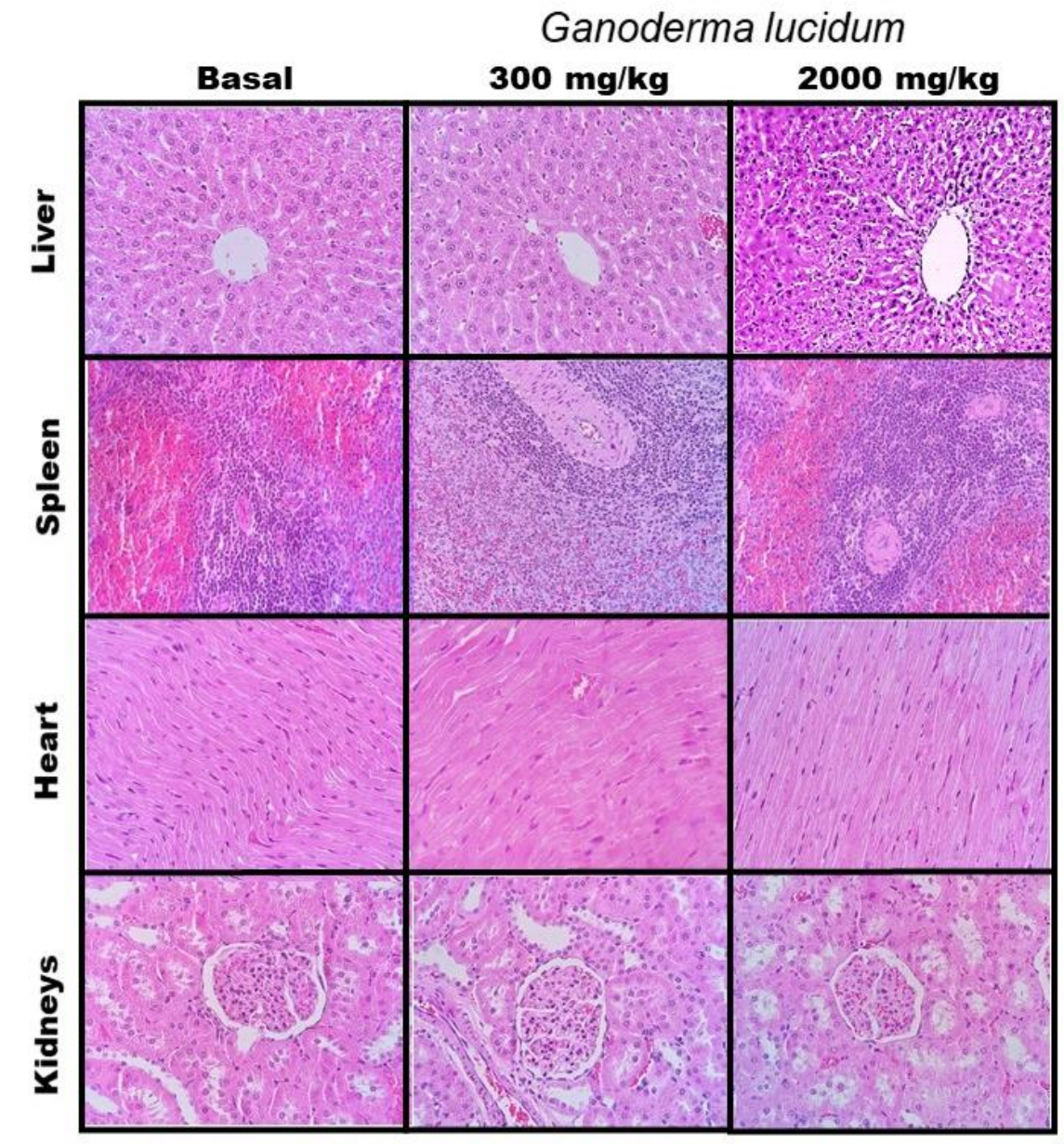

\section{DISCUSSION}


The present study tested the acute toxicity of lithium bioaccumulated in mycelial biomass of the Ganoderma lucidum in Wistar rats as proposed by OECD guideline 423. No changes in body mass or relative organ mass were observed in the animals, with no changes in biochemical, hematological, or histopathological parameters. Our findings indicate that acute oral treatment with 300 and $2000 \mathrm{mg} / \mathrm{kg}$ of this substance is nontoxic over 14 days in rats when administered at single dose.

In preclinical toxicology studies, hematopoietic evaluations are recommended as an important way to evaluate the toxicity profile of a substance and as a pathological index (ADENEYEA et al., 2006). Several biochemical parameters are important for explaining the toxicity of test substances (PETTERINO and ARGENTINO-STORINO, 2006). The profile of liver function (aspartate and alanine aminotransferase) and kidney function (urea and creatinine) are important predictors of the possible hepatic and renal toxicity of drugs (HILALY et al., 2004). Hematopoietic and biochemical changes can be reflected by cellular changes, assessed by histopathological examination (MATSUZAWA et al., 1995). In the present study, no alterations of hematological, biochemical, or histopathological parameters were found in rats that were acutely treated with lithium bioaccumulated in mycelial biomass of G. lucidum bioaccumulated with lithium at the $2000 \mathrm{mg} / \mathrm{kg}$ dose, indicating that this substance is nontoxic to the hematopoietic system, including the liver, kidneys, spleen, and heart. These results suggest possibilities of further preclinical studies of the effectiveness of this natural product with bioaccumulated lithium in animal models of anxiety, depression, and bipolar disorders.

The use of lithium for the acute treatment of bipolar disorder involves several aspects. The mood phase of bipolar disorder can move to the depressive phase before the euthymic state is reached. One disadvantage of lithium is that it can cause adverse effects, such as drowsiness, psychomotor retardation, and akathisia, which can mimic changes in mood (YILDIZ et al., 2011; KIM et al., 2017). Lithium carbonate has been the drug of choice for the treatment of bipolar disorder and is absorbed in the digestive system. For therapeutic purposes, it is necessary to reach a plasma concentration between 5.6 and 8.4 $\mathrm{mg} / \mathrm{L}$. The toxic concentration of the drug is above $10.5 \mathrm{mg} / \mathrm{L}$, thus indicating its narrow therapeutic index (ORUCH et al., 2014; SMITH and CIPRIANI, 2017). However, the 
adverse effects of lithium are dose-dependent. A lower dose of lithium restricts its adverse side effects (ALBERT et al., 2014).

One of the difficulties in using lithium is the therapeutic index for treatment. The association of lithium with more complex molecules that are present in basidiomycetes is one interesting strategy to control the solubility and availability of lithium, which may help control release of the ion throughout the digestive system and thus mitigate the likelihood of triggering adverse effects. Such controlled release occurs through the association of ions with complex organic compounds, such as proteins and polysaccharides, that are slowly digested and release minerals throughout the digestion process. Previous studies have reported the bioaccumulation of metals in fungi as one approach to increase the availability or minimize the side effects of certain substances or metals of interest, including zinc, iron, and lithium (AIDA et al., 2009; MARCANTE et al., 2014; ALMEIDA et al., 2015; YOKOTA et al., 2016). However, for detailed pharmacological studies to assess the effectiveness of lithium bioaccumulated in $G$. lucidum, toxicity studies are first necessary. Although a lack of efficacy is an important cause for eliminating candidates in final stages of drug development, toxicity needs to be identified in preclinical studies before such drugs reach the clinical phase. The predictive validity of observations in animal safety studies has improved over time as more reliable methodologies have been developed (CLARK and STEGER-HARTMANNB, 2018).

Science continually works to develop alternative strategies to decrease the number of animals that are used in toxicity studies and improve predictability and safety assessments (PRIOR et al., 2020). However, although new approaches and alternatives are growing for screening purposes, many components of regulatory toxicological assessments still depend on animal research, which is likely to continue into the foreseeable future until more reliable alternatives are discovered and validated as substitutes for animal use, especially in pharmacokinetic studies of absorption, distribution, metabolism, and excretion ( $\mathrm{GOH}$ et al., 2015). Although animal toxicity studies remain necessary, the 3Rs (Reduce, Refine, Replace) of animal research are still applicable. Any data that are generated from animals must be relevant and used to minimize the risk of adverse effects in humans. Currently, application of the 3Rs in toxicological studies includes refinements in research projects that seek to promote animal welfare and consequently obtain more reliable data (SPOONER et al., 2019, KENDRICK et al., 2020), in addition to reducing the number of animals that are used by 
optimizing the size of the experimental groups (CHAPMAN et al., 2013). Thus, the correct conduct of toxicity studies can positively influence both preclinical and clinical investigations of the efficacy of new molecules, leading to a greater likelihood of translational success and reducing the final friction in the final stages of drug development (PRIOR et al., 2020).

\section{CONSLUSION}

Lithium bioaccumulated in mycelial biomass of the Ganoderma lucidum did not induce signs of toxicity in rats that were acutely orally treated. However, further studies that test multiple dosing of lithium bioaccumulated in mycelial biomass of G. lucidum are required to better determine the comprehensive toxicity profile of this substance.

\section{ACKNOWLEDGEMENTS}

This research was supported by grants from Coordenadoria de Pós-Graduação (COPG; UNIPAR, Brazil), Conselho Nacional de Desenvolvimento Científico e Tecnológico (CNPq), and Fundação Araucária, Paraná/SETI (Brazil, CP 20/2018, 014/2020). The authors thank the Laboratório Reunidos for conducting the biochemical and hematological evaluations and Michael Arends for proofreading the manuscript.

\section{CONFLICT OF INTEREST}

The authors declare that there is no conflict of interest in this research.

\section{REFERÊNCIAS}

ADENEYE, A. A. et al. Preliminary toxicity and phytochemical studies of the stem bark aqueous extract of Musanga cecropioides in rats. Journal of ethnopharmacology, v. 105, n. 3, p. 374-379, 2006.

AIDA, F. M. N. A. et al. Mushroom as a potential source of prebiotics: a review. Trends in Food Science \& Technology, v. 20, n. 11-12, p. 567-575, 2009.

ALBERT, U. et al. Lithium treatment and potential long-term side effects: a systematic review of the literature. Rivista di Psichiatria, v. 49, n. 1, p. 12-21, 2014. 
ALMEIDA, R. N. et al. Metodologia para avaliação de plantas com atividade no sistema nervoso central e alguns dados experimentais. Revista Brasileira de Farmácia, v. 80, p. 72-76, 1999.

ALMEIDA, S. M. et al. Iron bioaccumulation in mycelium of Pleurotus ostreatus. Brazilian Journal of Microbiology, v. 46, p. 195-200, 2015.

CARDOSO, T. et al. Neuroprogression and cognitive functioning in bipolar disorder: a systematic review. Current psychiatry reports, v. 17, n. 9, p. 1-24, 2015.

CHAPMAN, K. L. et al. Pharmaceutical toxicology: designing studies to reduce animal use, while maximizing human translation. Regulatory Toxicology and Pharmacology, v. 66, n. 1, p. 88-103, 2013.

CHI-TSO, C. H. I. U.; CHUANG, D.M. Neuroprotective action of lithium in disorders of the central nervous system. Zhong nan da xue xue bao. Yi xue ban= Journal of Central South University. Medical sciences, v. 36, n. 6, p. 461-476, 2011.

CLARK, M.; STEGER-HARTMANN, T. A big data approach to the concordance of the toxicity of pharmaceuticals in animals and humans. Regulatory Toxicology and Pharmacology, v. 96, p. 94-105, 2018.

FARIA, M. G. I. et al. Lithium bioaccumulation in Lentinus crinitus mycelial biomass as a potential functional food. Chemosphere, v. 235, p. 538-542, 2019.

GOH, J.Y. et al. Development and use of in vitro alternatives to animal testing by the pharmaceutical industry 1980-2013. Toxicology Research, v. 4, n. 5, p. 1297-1307, 2015.

HILALY, J. E.; ISRAILI, Z. H.; LYOUSSI, B. Acute and chronic toxicological studies of Ajuga iva in experimental animals. Journal of ethnopharmacology, v. 91, n. 1, p. 43-50, 2004.

KENDRICK, J. et al. A novel welfare and scientific approach to conducting dog metabolism studies allowing dogs to be pair housed. Laboratory Animals, v. 54, n. 6, p. 588-598, 2020.

KIM, Y. et al. Molecular mechanisms of bipolar disorder: progress made and future challenges. Frontiers in cellular neuroscience, v. 11, p. 30, 2017.

LIMA, D. A. et al. Safety assessment of MEFAS: an innovative hybrid salt of mefloquine and artesunate for malaria treatment. Drug and Chemical Toxicology, v. 44, n. 4, p. 380-385, 2021.

MARCANTE, R. C. et al. Bioacumulação de zinco em micélio de Agaricus subrufescens. Arquivos de Ciências Veterinárias e Zoologia da UNIPAR, v. 17, n. 4, 2014.

MATSUZAWA, T. et al. Selection of appropriate parameters, use of a quality control concept, and suitable statistical analyses for clinical pathology examination of animals in toxicity studies: results of a current survey by the Japanese Pharmaceutical Manufacturers Association.

Comparative Haematology International, v. 5, n. 3, p. 196-200, 1995.

MATUTE, R. G. et al. Copper and zinc bioaccumulation and bioavailability of Ganoderma lucidum. Journal of Medicinal Food, v. 14, n. 10, p. 1273-1279, 2011.

MENIQUETI, A. B. et al. Iron-enriched mycelia of edible and medicinal basidiomycetes. Environmental Technology, p. 1-7, 2020. 
ORUCH, R. et al. Lithium: a review of pharmacology, clinical uses, and toxicity. European journal of pharmacology, v. 740, p. 464-473, 2014.

PERCIE DU SERT, N. et al. Reporting animal research: Explanation and elaboration for the arrive guidelines 2.0. PLoS Biology, v. 18, n. 7, p. 1-65, 2020.

STARK, Y. et al. Application of collagen matrices for cartilage tissue engineering.

Experimental and Toxicologic Pathology, v. 57, n. 4, p. 305-311, 2006.

PRIOR, H. et al. Justification for species selection for pharmaceutical toxicity studies.

Toxicology Research, v. 9, n. 6, p. 758-770, 2020.

SCHEID, S. S. et al. Iron biofortification and availability in the mycelial biomass of edible and medicinal basidiomycetes cultivated in sugarcane molasses. Scientific reports, v. 10, n. 1, p. 16,2020

SMITH, K. A.; CIPRIANI, A. Lithium and suicide in mood disorders: updated meta-review of the scientific literature. Bipolar Disorders, v. 19, n. 7, p. 575-586, 2017.

SOUZA, M. M. Q. et al. Baccharis trimera (Less.) DC: an innovative cardioprotective herbal medicine against multiple risk factors for cardiovascular disease. Journal of Medicinal Food, v. 23, n. 6, p. 676-684, 2020.

SPOONER, N. et al. Microsampling: considerations for its use in pharmaceutical drug discovery and development. Bioanalysis, v. 11, n. 10, p. 1015-1038, 2019.

UMEO, S. H. et al. Iron or zinc bioaccumulated in mycelial biomass of edible basidiomycetes. Anais da Academia Brasileira de Ciências, v. 92, 2020.

WARING, S. W.; WEBB, D. J.; MAXWELL, S. R. Lithium carbonate as a potential pharmacological vehicle: intravenous kinetics of single-dose administration in healthy subjects. European journal of clinical pharmacology, v. 58, n. 6, p. 431-434, 2002.

YILDIZ, A. et al. Efficacy of antimanic treatments: meta-analysis of randomized, controlled trials. Neuropsychopharmacology, v. 36, n. 2, p. 375-389, 2011.

YOKOTA, M. E. et al. Iron translocation in Pleurotus ostreatus basidiocarps: production, bioavailability, and antioxidant activity. Genetics and Molecular Research, v. 15, n. 1, p. 110, 2016.

Recebido em: 01/02/2022

Aprovado em: 25/02/2022

Publicado em: 02/03/2022 